\title{
СУЧАСНІ КОНЦЕПЦІЇ МЕНЕДЖМЕНТУ ТА ЇХ ЗАСТОСУВАННЯ В УМОВАХ ДІДЖИТАЛІЗАЦІЇ ЕКОНОМІКИ УКРАЇНИ
}

\author{
Володимир Васильович Гришко*, доктор економічних наук, професор, \\ заслужений економіст України \\ Національний університет «Полтавська політехніка імені Юрія Кондратюка»
}

*ORCID 0000-0001-9183-4008

(C) Гришко В., 2021.

Стаття отримана редакиією 17.03.2021 p.

The article received by the reduction 17.03.2021.

Постановка проблеми. Формування та розвиток нових економічних умов, що пов'язано 3 переходом до ринкових відносин, обумовило до необхідності зміни парадигми управління підприємствами та організаціями шляхом структурних і системних змін одночасно та відсутності дієздатних ринкових інституцій. Відсутність досвіду здійснення змін, управління в умовах змін, загострення внутрішніх проблем на підприємствах (розгортання одночасно криз (виробничої фінансової, кадрової, організаційної та інших), глобалізація, швидкий розвиток НТП обумовили потребу у нових підходах до системи управління як на рівні підприємства, так і галузі.

Слід зазначити, що зміни стали невід'ємною частиною процесу управління сучасними підприємствами i організаціями. Технологічні зміни, прискорений розвиток інформаційних, телекомунікаційних технологій призвели до необхідності пошуку нових підходів та концепцій управління, які б дозволяли забезпечувати життєво важливі інтереси суспільства та його сталий розвиток.

Аналіз останніх досліджень і публікацій. Дослідження теоретичних, методологічних та концептуальних аспектів менеджменту є актуальними останнє століття і залишається у центрі уваги сучасних теоретиків та практиків. Достатньо згадати фундаментальні праці Ф.Тейлора, Г. Форда, Ч.Барнадра, А.Файоля, М.Вебера, Г. Гантта, Е. Мейо, у П.Друкера, І.Ансоффа, Б.Карлоффа, Д.МакГрегорі, В.Оучі. Значний розвиток у сучасного менеджменту зробили Л. Балабанова, Л.Лепейко, Л. Скібіцька, В. Стадник, В. Черваньов, Ф.Хміль та інші. Однак, розвиток цифрових технологій актуалізує пошук концепції менеджменту, які дозволять формувати ефективну систему управління в умовах динамічних змін та високого рівня невизначеності зовнішнього середовища підприємства.

Метою статті $\epsilon$ представлення концептуальних засад становлення i розвитку сучасних концепцій менеджменту та їх застосування на сучасних підприємствах в умовах діджиталізації.

Виклад основного матеріалу. Менеджмент нараховує велику кількість наукових теорій i концепцій, які пов'язані із управлінням сучасних підприємств і без яких сучасному менеджеру не обійтися. Зокрема, системному підході, який дозволяє відобразити закони i закономірності функціонування підприємств як соціально-економічних систем. Так, у 20-х роках XX століття O.О.Богдановим у науковій праці «Общая организационная наука», був викладений перший варіант загальної теорії систем, яка наголошувала на необхідності використання закономірностей організації живої природи для пізнання соціальних явищ. В 40-х роках минулого століття Л. фон Берталанфі була сформульована сучасна концепція загальної теорії систем, яка розглядає систему як комплекс елементів, що знаходяться у процесі взаємодії.

Згідно цієї концепції, основна задача системної методології полягає у визначенні законів, які пояснюють поведінку, функціонування і розвиток систем різних класів [5]. Вводиться поняття як ентропія, підсистема, синергія, ресурси. Дозволяє менеджерам усвідомити необхідність усвідомлення основних принципів управління : цілісності, ієрархічності та взаємозалежності структури i середовища, що $є$ важливим при здійсненні організаційних змін, прийняття управлінських рішень та визначенні напрямів розвитку ( цілей та стратегіï). 
А. Файоль, який відноситься до класичної школи менеджменту сформував основні 14 принципів менеджменту (розподіл праці, наявність влади у одного суб'єкта, здатного ставити завдання та відповідати за підсумкові результати, єдність влади, результати діяльності, дисциплінованість, пріоритет загальних інтересів перед індивідуальними, стимулювання та винагорода працівників, централізований характер, необхідність взаємодії між керівником i підлеглими, суворий внутрішній порядок, рівність всіх членів організації, стабільність працівників, ініціативність та корпоративний дух) [5] та функції, які є важливими для організації процесу управління підприємством і не втратили актуальності сьогодні.

Складно уявити систему управління підприємством без процесу організації, планування, контролю, координації та адміністрування. Водночас, пандемія COVID - 19, актуалізувала питання організації дистанційної роботи у всіх сферах бізнесу та публічному управлінню. Продемонструвала важливість принципів управління при організації роботи підприємств і організацій в умовах тотальних обмежень (розподіл праці, дисциплінованість, необхідність взаємодії між керівником i підлеглими, ініціативність та корпоративний дух, єдність влади, результати діяльності, стимулювання та винагорода працівників). Саме принципи використовуються як правила, норми, що дозволяють структурувати всі процеси, комунікаційні канали та взаємовідносини в середині підприємства для досягнення поставлених цілей та в умовах високого рівня невизначеності. Зберігаючи при цьому здорові, робочі відносини у колективі.

Навіть, Франк Джільберт у своїх працях “Вивчення рухів як спосіб підвищити продуктивність за будь-якої роботи" звертав увагу на важливе значення дружніх стосунків між працівником i підлеглими, особливо якщо продуктивність кожного робітника окремо неможливо визначити [2, с. 9 ; 4, c.43].

Не втрачає своєї актуальності «теорія бюрократії» М. Вебера (1864-1920 роки), яка базується на чіткому розподілі праці, ієрархічності структури управління, точного ведення документообігу, послідовності правил, просуванню по кар'єрних сходинках на основі компетенцій та результатів роботи, а не особистих якостей.

Саме М.Вебер продемонстрував можливості знеособлення процесу управління, що дозволяє стандартизувати процес управління, що є важливим для нових підприємств, які тільки виникають і не розуміють як потрібно організувати цілеспрямовану роботу команди та керівника. В умовах пандемії, його підхід дозволяє уникати хаосу при організації процесу управління як у бізнесі, так i у адміністративній організації. Його документований підхід до управління на основі покладених функцій за своєю сталістю, суворістю, надійністю, інтенсивністю, ефективністю та точністю забезпечує єдність зусиль керівництва та працівників у досягненні поставлених цілей. Зокрема, такий підхід набуває важливого значення, коли ми здійснюємо автоматизацію процесів управління, впроваджуємо сучасні цифрові інформаційно-комунікаційні технології, виділяємо бізнес-процеси та реалізуємо програми державно-партнерського розвитку.

Здобутки цієї теорії не втрачаються і нині, коли розвивається цифрова економіка у світі та в Україні. I дозволяє знайти відповіді на запитання як ми повинні організовувати процес управління сучасними адміністративними організаціями та бізнес-структурами, щоб дотримуватись законодавства і забезпечувати розвиток в умовах динамічних змін.

Глобалізації, розвиток НТП та сучасних інформаційних систем актуалізує і питання продуктивності праці, яким займалися представники наукової школи менеджменту, зокрема Ф.Тейлор (1856-1915). Саме він обгрунтував доцільність використання наукового методу при пошуку шляхів підвищення продуктивності праці на основі покращення (удосконалення) організації робочих місць за рахунок чого бізнес може бути більш ефективним і продуктивним.

Здобутки даної теорії нині закладені у системі організації і раціоналізації «5S», що відноситься до концепції «ощадливого виробництва» (Lean), яка грунтується на прагненні підприємства ліквідувати всі види втрат за допомогою залучення у процес управління кожного працівника та максимальної орієнтації на споживача, що передбачає виробляти стільки продукції, скільки вимагає ринок [3]. Концепція «ощадливого виробництва» актуалізувала інтерес до таких інструментів як:

- «Точно-вчасно» - система, зорієнтована на мінімізацію складських запасів шляхом організації частих поставок дрібними партіями;

- ТРМ - система, в основу якої покладено навчання основного виробничого персоналу обслуговуванню устаткування та виявленню неполадок власними силами;

- SMED - система, завдяки впровадженню якої забезпечується швидке переналагоджування виробничого устаткування; 
- «Канбан» - система оперативного управління виробництвом за допомогою спеціальних карток;

- «Дзідока» підхід, що запроваджує практику зупинки роботи обладнання чи лінії в цілому в разі загрози виникнення дефектів;

- «Кайдзен» - підхід, що втілює в собі ідеологію неперервності вдосконалення окремих процесів і потоку створення цінності в цілому тощо [3, с.19 ].

Ці концепції ощадливого виробництва на сучасному етапі перетворюються у дієздатні та ефективні інструменти менеджера, що дозволяють забезпечувати сталий розвиток, де одним із ключових факторів є людський чинник.

Ринкова система господарювання відкрила безліч можливостей для реалізації людського потенціалу, який досліджували представники школи людських та поведінкових наук. I майже через п’ятдесят років не втрачається їх актуальність.

Школа людських відносин (1930 - 1950 рр.) пов’язана з іменами таких видатних вчених як Фрід Ротлісбергер, Абрахаам Маслоу, Дуглас МакГрегор, Гюго Мюнстерберг, Елтон Мейо, Мері Паркер Фоллет, Честер Барнард. Основною ідеєю цієї школи є створення умов. Коли працівники можуть максимально реалізувати свій потенціал, що забезпечить організаційний розвиток та організаційну ефективність.

У книзі «Людська сторона підприємництва» (1960р.) Д.Макгрегор, як зазначив Дафт Р. [2] визначив, що керівник будує свою поведінку щодо підлеглих відповідно до своїх особистих уявлень про працівників та їхні здібності. Тому керівник має змогу використовувати дві системи.

Перша - «Х», коли працівники не полюбляють працювати і прагнуть уникати роботи i контролю; вони прагнуть до захищеності; для їх стимулювання потрібно використовувати погрози та покарання. У результаті виникає потреба у автократичному стилі керівництва. Друга- «Ү» протилежний підхід, який передбачає, що працівники розглядають працю як природній процес. Тому вони не тільки будуть працювати і брати на себе відповідальність, але і будуть у ній зацікавлені. Вони будуть використовувати самоврядування i самоконтроль. Завдяки цьому сформувався демократичний стиль управління.

Як продемонструвала практика, кожний підхід має своїх прихильників і дозволяє досягати поставлених цілей, але потребує врахування низки різноманітних чинників. 3 часом дана теорія була доповнена Уільямом Уочі, який сформував теорію «Z» [12]. В основі цієї теорії лежить принцип колективізму та корпоративного духу, коли працівник несе індивідуальну відповідальність за результати своєї праці, а результати роботи оцінюються згідно чітких критеріїв. Працівникові надається можливість безперервного і постійного підвищення кваліфікації. Тобто, організаційний розвиток і організаційна ефективність будуть досягати за рахунок корпоративних цінностей, а саме : довіри, солідарності, відповідальності. Це набуває важливого значення в умовах діджиталізації економіки та впровадження дистанційної організації роботи сучасних підприємств і адміністративних організацій. Оскільки за їх відсутності стає складно координувати, об'єднувати та мотивувати працівників, коли вони знаходяться за межами організації.

М. П. Фоллет досліджувала проблеми, які є актуальними і сьогодні: влада, лідерство, етика, підвищення продуктивності праці персоналу, вплив процесу постановки цілей на кількість конфліктів в організації, ефективна взаємодія менеджерів з організацією в цілому[12].

Праці науковців школи людських відносин та поведінкових наук послугували основою розвитку сучасних моделей організаційного розвитку, які розвиваються до цього часу.

Зокрема, розвиток поведінкових наук, демонстрація вигід від децентралізації, переваги від командної роботи, відкритий обмін знаннями призвів до зміни підходів організаційного розвитку.

Як зазначає Г. МакЛін на початку XXI століття, що організаційний розвиток це «будь-який процес або діяльність, яка базується на поведінкових науках, які, або із самого початку або через довгий час, мають потенціал розвивати, в межах організаційного середовища, вдосконалені знання, експертний досвід, продуктивність, задоволеність, дохід, міжособистісні відносини, та або інші бажані результати, або для персональної або групової / командної користі, або для виграшу організації, спільноти, нації, регіону, або, зрештою, всього людства» [13]. Зокрема, хронологія моделей організаційного розвитку дозволяє продемонструвати синергію системного, процесного та ситуаційного підходу, досягнень школи людських та поведінкових наук до процесу управління, яке орієноване на організаційний розвиток (табл.1). 
Хронологія формування сучасних моделей організаційного розвитку*

\begin{tabular}{|c|c|c|}
\hline Рік & Назва моделі & Коротка характеристика \\
\hline $\begin{array}{l}\text { 50-ті pp. } \\
\text { XX ст. }\end{array}$ & Модель Е. Демінга & 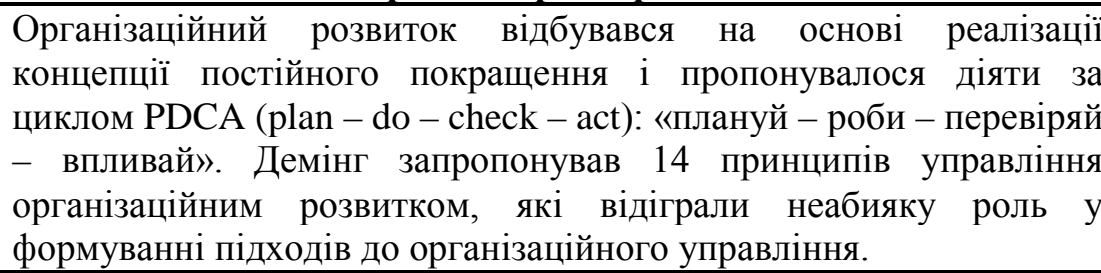 \\
\hline 1972 & Модель К. Левіна & $\begin{array}{l}\text { Організаційний розвиток відбувається за трьохфазним циклом: } \\
\text { «розморожування - зміна - заморожування» }\end{array}$ \\
\hline 1972 & Модель Л. Грейнера & $\begin{array}{l}\text { Організаційний розвиток є процесом послідовної зміни } \\
\text { революційних та еволюційних фаз, що має п’ять етапів } \\
\text { зростання: креативність, директивне керівництво, делегування, } \\
\text { координація та колаборація }\end{array}$ \\
\hline 1978 & $\begin{array}{l}\text { Модель «Айсберга» } \\
\text { С. Н. Германа }\end{array}$ & $\begin{array}{l}\text { Передбачає організаційний розвиток через неформальні } \\
\text { відносини, щоб гарантувати підтримку членами організації цілей, } \\
\text { завдань, стратегій і політики. }\end{array}$ \\
\hline 1976 & $\begin{array}{l}\text { Шестиелементна } \\
\text { Модель М. Вейсборда }\end{array}$ & $\begin{array}{l}\text { Організаційний розвиток - це пошук відповідності між вимогами } \\
\text { зовнішнього оточення та організацією; відповідності між } \\
\text { вимогами організації та індивідуумом. Шість елементів моделі } \\
\text { такими: цілі, структура, винагорода, допоміжні механізми, } \\
\text { відносини, лідерство як центральний компонент. }\end{array}$ \\
\hline $\begin{array}{l}1979, \\
1990\end{array}$ & $\begin{array}{l}\text { Модель життєвого } \\
\text { циклу I. Адізеса }\end{array}$ & $\begin{array}{l}\text { Організаційний розвиток розглядається як комплексний процес із } \\
\text { фаз зростання та занепаду. Стверджується, що існує шість стадій } \\
\text { розвитку: залицяння, малоліття, бурхливі роки (оригінальна назва } \\
\text { «Давай-давай»), юність, ранній та пізній розквіт. Стадії деградації } \\
\text { включають в себе аристократизм, Салем-сіті (оригінальна назва } \\
\text { «Рекрімінація»), бюрократію та смерть. }\end{array}$ \\
\hline 1980 & $\begin{array}{lr}\text { МакКінсі } & \text { 7-S Рамкова } \\
\text { Модель } & \text { (автори } \\
\text { Р. Уотерман } & \text { та } \\
\text { T. Пітерс) } & \end{array}$ & $\begin{array}{l}\text { Організація розглядається як сукупність семи елементів: } \\
\text { стратегія, структура, системи, персонал, стиль, навички, розділені } \\
\text { цінності. Розвиток відбувається за всіма компонентами } \\
\text { неодночасно, неоднорідно, і тому культура стає визначальним } \\
\text { елементом організаційних змін. }\end{array}$ \\
\hline 1986 & $\begin{array}{l}\text { Модель розірваної } \\
\text { рівноваги (Т.Романеллі, } \\
\text { М.Тушман, } \\
\text { Дж.Ньюман) } \\
\end{array}$ & $\begin{array}{l}\text { Організаційний розвиток розглядається через тривалі періоди } \\
\text { рівноваги, які перериваються революційними періодами. Це } \\
\text { досягається за рахунок двох типів змін: «налаштування» } \\
\text { «безперервної адаптації до змін у зовнішньому середовищі» }\end{array}$ \\
\hline 1992 & Модель Бурке-Літвін & $\begin{array}{l}\text { Організаційний розвиток є багатошаровою системою, в якій } \\
\text { елементи пов'язані між собою у транзакційних та } \\
\text { трансформаційних вимірах. При цьому встановлена роль } \\
\text { трансформаційних та трансакційних лідерів, зв'язків між } \\
\text { елементами та їх ефективність. }\end{array}$ \\
\hline 2006 & $\begin{array}{l}\text { Модель організаційної } \\
\text { трансформації Дойля- } \\
\text { Стерна }\end{array}$ & $\begin{array}{l}\text { Організаційна трансформація спрямована на вирішення } \\
\text { невідповідності між вимогами оточення та можливостями } \\
\text { організації та містить такі стадії, як: 1) оцінка зовнішніх сил } \\
\text { трансформації галузі, 2) розроблення концепції лідерства в галузі; } \\
\text { 3) розроблення програми побудови ключових компетенцій для } \\
\text { досягнення цілей конкурентоспроможності, 4) розроблення та } \\
\text { вибір конкретних стратегій та підходів трансформаційного } \\
\text { лідерства. }\end{array}$ \\
\hline 2007 & $\begin{array}{l}\text { Зіркова Модель } \\
\text { Кейтс-Галбрайта }\end{array}$ & $\begin{array}{l}\text { Організація представлена як п’ятиелементна система, що } \\
\text { складається із стратегії, структури, процесів, винагороди та людей } \\
\text { (персонал). }\end{array}$ \\
\hline
\end{tabular}

*Узагальнено на основі [7, 8, 9-14,] 
Таким чином, ці моделі демонструють можливості формування сучасних систем управління на основі організаційних змін, які стають невід'ємною частиною процесу функціонування та розвитку підприємств і адміністративних організацій.

Їх реалізацію неможливо уявити без використання ситуаційного та процесного підходів, які виникли у $60-\mathrm{x}$ роках $\mathrm{XX}$ століття, які створили базис сучасних концепцій, які широко використовуються у світовій практиці та впроваджують в Україні. До них слід віднести:

- концепцію реінжинірингу бізнес-процесів або концепція Business Process Reengineering, яка передбачає радикальне перепроектування основних бізнес-процесів з метою отримання радикальних покращень основних показників;

- концепцію проектно-орієнтованого командного управління, яка орієнтована на визначенні бізнес-процесів, використанні сучасних інформаційних технологій та формуванні проектних команд;

- концепцію тотального управління якістю, яка формувалася останні п’ять десятиліть в основі якої закладена реалізація принципів роботи з документами, тобто застосування технічної документації, системи контролю за браком та дефектами, відповідної посади інспектора по якості, санкцій, мотивації. Таким чином, система управління якістю інтегрується у кожний виробничий процес технологічного циклу на виробництві та орієнтована на постійне поліпшення якості, мінімізацію витрат та постачання продукції вчасно. Ключовим фактором успіху цієї системи $\epsilon$ працівник, який максимально залучається до всіх процесів, проходить навчання, стимулювання $\mathrm{i}$ професійний розвиток.

- концепцію управління ефективністю бізнесу (Business Performance Management), яка використовується для опису методологій, процесів або робочих процесів, метрик та систем, які організація використовує для управління та оптимізації результатів бізнесу. Метою ВРМ є надання можливості організації досягти своїх цілей якомога ефективніше. Це досягається використанням наявних ресурсів, включаючи людей, для розробки та реалізації стратегії, яка буде реалізовуватися через його структуру.

Висновки. Таким чином, ці концепції дозволяють забезпечувати адаптації ієрархічних структур до динамічних змін. I дозволяють використовувати можливості діджиталізації для організаційного розвитку, а саме: надання додаткової цінності товару за рахунок якісного сервісу; посилення зв'язку із цільовими аудиторіями, клієнтами та постачальниками; підвищення рівня лояльності клієнтів до підприємства; прозорості всіх процесів; зниження ціни за рахунок автоматизації основних та додаткових бізнес-процесів.

Перспективи подальших досліджень у дослідження сучасних концепції розвитку, які сприятимуть сталому розвитку економіки України.

\section{СПИСОК ВИКОРИСТАНОЇ ЛІТЕРАТУРИ:}

1. Барнард Ч (2009). Функции руководителя: власть, стимулы и ценности в организаџии. М.

2. Дафт Р. (2007). Менеджмент. СПб.

3. Омельяненко Т.В., Щербина О.В., Барабась Д.О., Вакуленко А.В. (2009). Ощяадиве виробництво: концепиія, інструменти, досвід. К.

4. Питерс Т., Уотермен Р. (1986). В поисках еффективного управления: Опыт лучших компаний. М.

5. Рульєв В. А, Гуткевич С. О. (2011) Менеджмент. К.

6. Слєпцов I. О. Емерсон Г (1993). Дванадиять приниипів продуктивності// Наука управляти: з історії менеджменту. К.

7. Швіндіна Г.О. (2016). Визначення основних елементів моделі управління організаційним розвитком на підприємстві. Український журнал прикладної економіки. Том 1. №4. С. 147-156.

8. Янковець Т.М., Лазарєва М.О (2016). Сучасні концепції менеджменту: закордонний досвід // [Інформаційно-аналітичне забезпечення ефективності діяльності підприємств у контексті економічної безпеки в умовах інтеграції з СС]: матеріали Міжнародної науково_практичної інтернетконференції, (27 травня 2016 р.) , м. Київ. К.: КНУТД. С. 205-207.

9. Deming, W. E. (1991). Quality, productivity, and competitive position [Electronics Source]: Retrieved from: http://gpsinc. us/files/Deming.pdf.

10. Doyle P. \& Stern, P. (2006). Marketing management and strategy. Pearson Education. 446 p.

11. Greiner, L.E. (1997) Evolution and revolution as organizations grow / Harvard business review, Reprinted from 1972. № 76(3). Pp.55-60. 
12. Kates, A. Designing your organization: using the star model to solve 5 critical design challenges

13. McLean, G. (2005). Organization Development: Principles, Processes, Performance. BerrettKoehler Publishers.

14. Waterman, R. H. (1980). Structure is not organization / R.H. Waterman, T.J. Peters, J. R. Phillips // Business horizons. N 23(3). P. 14-26.

\section{REFERENCES :} Press, $334 \mathrm{p}$.

1. Barnard, Chester (1938). The Functions of the Executive. Cambridge, MA: Harvard University

2. Daft Richard L. (2009). Management. 9th ed. Cengage Learning. 704 p.

3. Lean manufacturing: concept, tools, experience: scientific and practical. ed. / T. V. Omelyanenko, A. V. Shcherbina, D. A. Barabas, A. V. Vakulenko; Ministry of Education and Science of Ukraine; DVNZ "Kyiv. nat. econom. un-t them. Vadim Getman ". Kiev, KNEU, 2009. 157 p.

4. Peters Thomas J. \& Waterman, Jr. Robert H. (1982). In Search of Excellence: Lessons from America's Best-Run Companies. New York: Harper \&Row. $312 p$.

5. Rulev VA, Gutkevich SO (2011). Management. Textbook. Kyiv: Center for Educational Literature.

6. Sleptsov I.A., Emerson G (1993). Twelve Principles of Productivity // The Science of Management: A History of Management. TO.

7. Shvindina G.A. (2016). Determination of the main elements of the organizational development management model of the enterprise. Ukrainian Journal of Applied Economics. Vol. 1.No.4. Pp. 147-156.

8. Yankovets T.M., Lazareva M.O (2016). Modern concepts of management: foreign experience [Information and analytical support of the efficiency of enterprises in the context of economic security in the context of integration with the EU]: materials of the International scientific practical Internet conference, (May 27, 2016), Kiev. KNUTD. Pp. 205-207.

9. Deming, W. E. (1991). Quality, productivity, and competitive position [Electronics Source]: Retrieved from: http://gpsinc. us/files/Deming.pdf. [in English] English]

10.Doyle P. \& Stern, P. (2006). Marketing management and strategy. Pearson Education. 446 p. [in

11.Greiner, L.E. (1997). Evolution and revolution as organizations grow. Harvard business review, Reprinted from 1972. № 76(3). Pp.55-60. [in English]

12.Kates, A. Designing your organization: using the star model to solve 5 critical design challenges. [in English]

13.McLean, G. (2005). Organization Development: Principles, Processes, Performance. BerrettKoehler Publishers. [in English]

14.Waterman, R. H., Peters, T.J., Phillips, J. R. (1980). Structure is not organization. Business horizons. N 23(3). Pp. 14-26.

УДК 65.012.23.001.11

JEL O15, O32, D11

Гришко Володимир Васильович, доктор економічних наук, професор, заслужений економіст України. Національний університет «Полтавська політехніка імені Юрія Кондратюка». Сучасні концепції менеджменту та їх застосування в умовах діджиталізації економіки України. Проаналізовано основні теорії менеджменту, які $€$ актуальними для сучасних підприємств та організацій. Визначено, що здобутки наукової та класичної школи менеджменту доцільно використовувати в умовах пандемії COVID- 19. Зокрема, врахування таких принципів як: розподіл праці, дисциплінованість, необхідність взаємодії між керівником і підлеглими, ініціативність та корпоративний дух, єдність влади, результати діяльності, стимулювання та винагорода працівників. Це дозволить структурувати всі процеси та взаємовідносини всередині підприємства для досягнення поставлених цілей та в умовах високого рівня невизначеності. Праці науковців школи людських відносин та поведінкових наук послугували основою розвитку сучасних моделей організаційного розвитку в умовах поширення цифрових технологій та діджиталізації економіки. Цифрові технології як створюють нові можливості для розвитку сучасних підприємств, так і формують нові виклики. Саме знання здобутків науковців та практиків 3 менеджменту дозволить сучасному менеджеру забезпечити сталий розвиток підприємств. 
Ключові слова: концепція, менеджмент, модель, організаційний розвиток, генезис, сталий розвиток.

UDC 65.012.23.001.11

JEL O15, O32, D11

Hryshko Volodymyr, Doctor of Sciences (Economics), Professor, Honored Economist of Ukraine. National University "Yuri Kondratyuk Poltava Polytechnic". Modern Concepts of Management and Their Application in the Context of the Digitalization of the Ukrainian Economy. The author analyzes the main theories of management that are relevant for modern and administrative organizations. It was determined that the achievements of the scientific and classical school of management are advisable to use in the context of the COVID-19 pandemic, including such principles as division of labor, discipline, the need for interaction between the manager and subordinates, initiative and corporate spirit, unity of power, performance results, incentives and rewards workers. This will allow structuring all processes and relationships within the enterprise in order to achieve the set goals and in conditions of a high level of uncertainty. The work of researchers at the School of Human Relations and Behavioral Sciences served as the basis for the development of modern models of organizational development in the context of the spread of digital technologies and the digitalization of the economy. Since digital technologies both create new opportunities for the development of modern enterprises and create new challenges. It is the knowledge of the achievements of scientists and management practitioners that will allow a modern manager to ensure the sustainable development of enterprises.

Key words: concept, management, model, organizational development, genesis, sustainable development 